\title{
Distribution Optimization Using Ant Colony Optimization (ACO) Method Case Research: PT. Coca Cola Official Distributor of Surabaya Area
}

\author{
Rusindiyanto*, Nur Rahmawati, Muhammad Andriven Gozali Sutejo \\ Industrial Engineering Department, UPN “Veteran” Surabaya, East Java, Indonesia
}

*Correspondence Author
E-mail:
rusindiyanto4@gmail.com

\begin{abstract}
PT.Coca-Cola Amatil Indonesia is a manufacturing company that produces beverages such as soft drinks, tea, milk, juice, isotonic and mineral water, located in Pandaan. This company has a distribution area that is spread almost all over Indonesia. In the Surabaya area, the company has 30 kiosks/salesmen as partners. The distribution of products in the Surabaya area is done through Take Order (TO) sales. The final product is distributed to consumers through third parties. The purpose of this research is to determine the distribution route with the shortest distance. The distribution problem experienced by this company is better known as the Traveling salesman problem (TSP). TSP is a combinatorial problem where when the problems faced are increasingly complex, the time needed is also getting longer. Several methods for solving TSP have been proposed. One of the best is the metaheuristic method, one of which is Ant Colony Optimization (ACO). In this research, the ACO method is used to solve the TSP problems encountered. The routes generated from the ACO method are $41.3 \mathrm{~km}$ which is $9.03 \%$ shorter than the actual route.
\end{abstract}

Keywords: Distribution problem, traveling salesman problem, ant colony optimization

\section{Introduction}

The traveling salesman problem (TSP) aims to find the shortest travel route with several destination cities with certain lines where each city is only allowed visited once and the trip ends with returning to the original city (Lukman et al., 2011). TSP is categorized as an NP-hard problem with a high number of possible solutions (Halim \& Ismail, 2019) which means that the minimum expected time to obtain optimal solution is exponential (Brezina \& Čičková, 2011). Therefore, a metaheuristic approach is proposed to produce the best solution.

Metaheuristic methods have been widely used in previous researches. For some problems, this method can even provide optimal results with a comparatively shorter calculation time (Rahmawati \& Santosa, 2017). Some of the problems that can be solved using this method include the problem of machine scheduling (Kundakc1 \& Kulak (2016) using the hybrid genetic algorithm method in the job shop scheduling problem, Utama et al. (2019) which uses cross entropy- genetic algorithm in flow shop sceduling problem to get minimal total tardiness, and also Ying and Lin (2020) who use simulated annealing for job shop scheduling without waiting time), project scheduling (Rahmawati \& santosa (2016) that uses cross entropygenetic Algorithm for solving Resource-Constrained Project Scheduling Problem, Kadri and Boctor (2018) using genetic algorithm to solve the resource-constrained project scheduling problem with transfer times and also Lin et al. (2020) which used genetic programming hyper-heuristic approach to the multi-skill resource constrained project scheduling problem), as well as distribution problems (Erdianto et al. (2019) who used genetic algorithms and nearest neighbors to find distribution routes, Santosa et al. (2016) that

How to cite:

Rusindiyanto, Rahmawati, N., \& Sutejo, A. G. (2020). Distribution optimization using Ant Colony Optimization (ACO) method case research: PT. Coca Cola official distributor of Surabaya area. $1^{\text {st }}$ International Conference Eco- Innovation in Science,

Engineering, and Technology. NST Proceedings. pages 248-252. doi:10.11594/ nstp.2020.0540 
used a hybrid cross entropy-genetic algorithm to solve multi-product inventory ship routing with a heterogeneous fleet model, Zang and Xiong (2018) that used ant colony optimization to find the best routes, and also Khadijah and Hasanah (2019) that used tabu search and differential evolution to find distribution routes) and many more.

In this research, the ant colony optimization (ACO) method which is part of Metaheuristic Methods is used to solve the distribution problems that occur. ACO was chosen because ACO was proven could produce the best route for distribution problems (Fahmi et al., 2020).

\section{Research Method}

The method used to solve the TSP problem in this research is the Ant Colony Optimization (ACO) method. Table 1 below is the destination location data. There are 34 demand nodes in the Surabaya area in November 2019. The first node in the table, CCOD Surabaya, is the origin node which is the location of the distribution center in Surabaya.

Table 1. Demand in November 2019

\begin{tabular}{|c|c|c|}
\hline No & Kios & Address \\
\hline 1 & CCOD SURABAYA & Rungkut Industri I no 27 \\
\hline 2 & Kios Nada & Wonorejo Timur no13 \\
\hline 3 & Kop Sejahtera Bersama & Embong Trengguli no 5-7 \\
\hline 4 & Toko Buku Immanuel & Pregolan no 27 \\
\hline 5 & Depot Kanya Food & Wonorejo Selatan gg 6 no 17 \\
\hline 6 & Toko Primagama & Wonorejo Selatan no 57 \\
\hline 7 & Toko Mitra Abadi & Rungkut Madya no 245k \\
\hline 8 & Kolam Pancing Bumi Gacar & Wonorejo Selatan no 1 \\
\hline 9 & Apotek Pradana & Perum. Rungkut Asri Timur no 24 \\
\hline 10 & Toko Sams Bakery & Rungkut Madya no 157 \\
\hline 11 & Toko Barokah Makur & Medokan Sawah no 52 \\
\hline 12 & Apotek K-24 Medokan & Medokan Sawah no 9a \\
\hline 13 & Warung Salam & Wonorejo Timur no 1 \\
\hline 14 & Toko Mandiri & Wonorejo no 1 \\
\hline 15 & Salon Emelda & Nirwana Eksekutive bb 386a \\
\hline 16 & Warung Kopi Cak Agus & Wonorejo Selatan no 142 \\
\hline 17 & Toko Ibu Sumaji & Wonorejo Selatan 2 no 108 \\
\hline 18 & Yamaha Lestari Jaya Motor & Raya Pandugo no 45 \\
\hline 19 & Kedai Ayam Geprek EGP & Raya Pandugo no 76 \\
\hline 20 & Yuan Cell & Raya Pandugono no 39 \\
\hline 21 & Toko Banana Speed & Rungkut Madya no 117 \\
\hline 22 & Toko Sofi Jaya & Medokan Sawah no 119 \\
\hline 23 & Toko Baru & Medokan Kampung gg TK no 1 \\
\hline 24 & Toko Putra Bangsa & Putra Bangsa no 1 \\
\hline 25 & Toko Madinah & Taman Rivera Regency no 8 \\
\hline 26 & Rujak Ibu Nono & $\begin{array}{l}\text { Medayu Selatan } 2 \text { no } 16 \\
\text { To be continued... }\end{array}$ \\
\hline
\end{tabular}




\begin{tabular}{lll}
\hline No & \multicolumn{1}{c}{ Kios } & \multicolumn{1}{c}{ Address } \\
\hline 27 & Warung Mas Bro & Medokan Sawah no 116 \\
28 & Waltel Ruzky & Medokan Ayu gg 1C no 18 \\
29 & Fotocopy Mitra Abadi & Medokan Sawah no 2 \\
30 & Surya Fotocopy and Print & Rungkut Madya no 31 \\
31 & Warung Kopi Wolu & Medokan Asri Timur no 10 \\
32 & Warung Kopi Satu & Medokan Asri 5 no 18 \\
33 & Kolam Renang & Rungkut Madya no 181 \\
34 & Toko Annisa & Rungkut Kidul YKP RK V Blok E \\
35 & Toko Cindy Jaya & Raya Medokan Semampir ni 18 \\
\hline
\end{tabular}

The ACO algorithm used in this research are (Hlaing \& Khine, 2010):

Procedure ACO algorithm for TSP

Set parameters, initialize pheromone trails

Loop

Each ant is positioned on a starting node

Loop

Construct Solutions

Apply Local Search

Local_Pheromone_Update

Until all ants have built a complete solution

Global_Pheromone_Update

Until End_condition

End ACO algorithm for TSPs

\section{Result and Discussion}

Table 2 below is a distribution route generated by the ACO algorithm. From this table, it is known that the first destination of the route is the Kopi Satu shop. While the last stall on the route is the Sams and Bakery shop following the sequence generated by the ACO algorithm.

Table 2. ACO Result

\begin{tabular}{ccll}
\hline No & Sequence & Kios & Address \\
\hline 1 & 1 & CCOD SURABAYA & Rungkut Industri I no 27 \\
2 & 7 & Toko Annisa & Rungkut Kidul YKP RK V Blok E \\
3 & 30 & Toko Banana Speed & Rungkut Madya no 117 \\
4 & 34 & Kolam Renang & Rungkut Madya no 181 \\
5 & 35 & Toko Sams Bakery & Rungkut Madya no 157 \\
6 & 3 & Toko Sofi Jaya & Medokan Sawah no 119 \\
7 & 4 & Toko Barokah Makur & Medokan Sawah no 52 \\
8 & 2 & Warung Kopi Satu & Medokan Asri 5 no 18 \\
9 & 13 & Warung Mas Bro & Medokan Sawah no 116 \\
10 & 14 & Rujak Ibu Nono & Medayu Selatan 2 no 16 \\
11 & 15 & Apotek K-24 Medokan & Medokan Sawah no 9a \\
12 & 8 & Toko Madinah & Taman Rivera Regency no 8
\end{tabular}




\begin{tabular}{ccll}
\hline No & Sequence & Kios & Address \\
\hline 13 & 16 & Waltel Ruzky & Medokan Ayu gg 1C no 18 \\
14 & 17 & Toko Baru & Medokan Kampung gg TK no 1 \\
15 & 5 & Toko Putra Bangsa & Putra Bangsa no 1 \\
16 & 6 & Depot Kanya Food & Wonorejo Selatan gg 6 no 17 \\
17 & 18 & Toko Ibu Sumaji & Wonorejo Selatan 2 no 108 \\
18 & 19 & Toko Primagama & Wonorejo Selatan no 57 \\
19 & 20 & Salon Emelda & Nirwana Eksekutive bb 386a \\
20 & 32 & Toko Cindy Jaya & Raya Medokan Semampir ni 18 \\
21 & 27 & Toko Buku Immanuel & Pregolan no 27 \\
22 & 22 & Kop Sejahtera Bersama & Embong Trengguli no 5-7 \\
23 & 11 & Kios Nada & Wonorejo Timur no13 \\
24 & 26 & Warung Salam & Wonorejo Timur no 1 \\
25 & 12 & Toko Mandiri & Wonorejo no 1 \\
26 & 25 & Kolam Pancing Bumi Gacar & Wonorejo Selatan no 1 \\
27 & 28 & Warung Kopi Cak Agus & Wonorejo Selatan no 142 \\
28 & 24 & Kedai Ayam Geprek EGP & Raya Pandugo no 76 \\
29 & 23 & Yuan Cell & Raya Pandugono no 39 \\
30 & 29 & Yamaha Lestari Jaya Motor & Raya Pandugo no 45 \\
31 & 9 & Fotocopy Mitra Abadi & Medokan Sawah no 2 \\
32 & 31 & Apotek Pradana & Perum. Rungkut Asri Timur no 24 \\
33 & 33 & Warung Kopi Wolu & Medokan Asri Timur no 10 \\
34 & 10 & Toko Mitra Abadi & Rungkut Madya no 245k \\
35 & 21 & Surya Fotocopy and Print & Rungkut Madya no 31 \\
\hline
\end{tabular}

The total distribution distance generated by following the sequence obtained from the ACO algorithm is $41.3 \mathrm{~km}$. The more iterations are generated, the more stable the results are obtained. From the results of running with the ACO algorithm (Figure 1), the results began to stabilize with a distance of $41.3 \mathrm{~km}$ on the 85 th iteration.

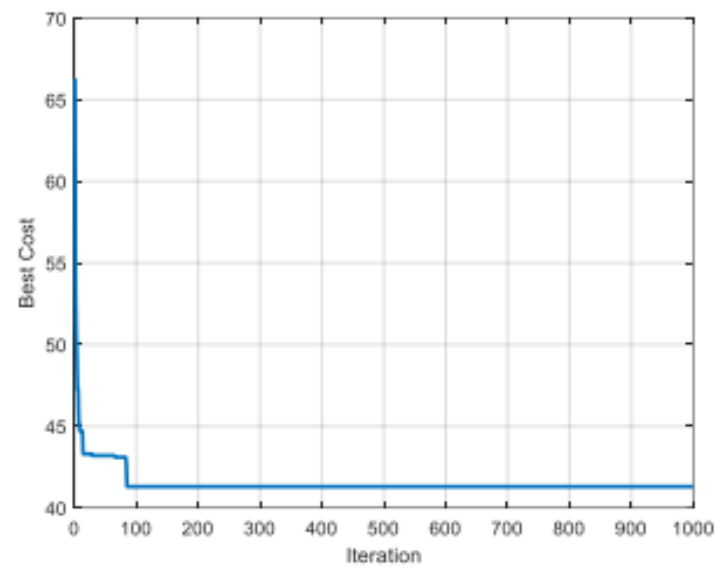

Figure 1. Iteration using ACO algorithm 


\section{Conclusion}

The results obtained from this research are the Ant Colony Optimization algorithm produced a total delivery distance of $41.3 \mathrm{~km}$ whereas if using the actual route, the total delivery distance is $45.4 \mathrm{~km}$. The Ant Colony Optimization algorithm method is proven to be able to save a distance of $4.1 \mathrm{~km}$ with a saving percentage of $9.03 \%$.

\section{Acknowledgment}

The authors would like to thank all related parties that support this research so that can be completed properly.

\section{References}

Brezina Jr, I., \& Čičková, Z. (2011). Solving the travelling salesman problem using the ant colony optimization. Management Information Systems, 6(4), 10-14.

Fahmi, H., Zarlis, M., Nababan, E. B., \& Sihombing, P. (2020, June). Ant Colony Optimization (ACO) Algorithm for Determining The Nearest Route Search in Distribution of Light Food Production. In Journal of Physics: Conference Series (Vol. 1566, No. 1, p. 012045). IOP Publishing

Halim, A. H., \& Ismail, I. (2019). Combinatorial optimization: comparison of heuristic algorithms in travelling salesman problem. Archives of Computational Methods in Engineering, 26(2), 367-380.

Hlaing, Z. C. S. S., \& Khine, M. A. (2010, December). An ant colony optimization algorithm for solving traveling salesman problem. Fifth Local Conference on Parallel and Soft Computing.

Kadri, R. L., \& Boctor, F. F. (2018). An efficient genetic algorithm to solve the resource-constrained project scheduling problem with transfer times: The single mode case. European Journal of Operational Research, 265(2), 454-462.

Khadijah, A., \& Hasanah, H. (2019, August). Optimization of CNG Multi-depot Distribution to Determine Model Routes and GTM Totals Using Tabu Search and Differential Evolution Methods. In Proceedings of the International Manufacturing Engineering Conference \& The Asia Pacific Conference on Manufacturing Systems (pp. 10-16). Springer, Singapore.

Kundakc1, N., \& Kulak, O. (2016). Hybrid genetic algorithms for minimizing makespan in dynamic job shop scheduling problem. Computers \& Industrial Engineering, 96, 31-51.

Lin, J., Zhu, L., \& Gao, K. (2020). A genetic programming hyper-heuristic approach for the multi-skill resource constrained project scheduling problem. Expert Systems with Applications, 140, 112915.

Lukman, A., Palapa, S. N., Rubinah, A. R., \& Rizky, A. M. I. K. (2011). Penyelesaian Travelling Salesman Problem dengan Algoritma Greedy.

Rahmawati, N., \& Santosa, B. (2017). Penerapan Algoritma Hybrid Cross Entropy-Genetic Algorithm Dalam Penyelesaian Resource-Constrained Project Scheduling Problem. Prosiding SENIATI, C37-1.

Santosa, B., Damayanti, R., \& Sarkar, B. (2016). Solving multi-product inventory ship routing with a heterogeneous fleet model using a hybrid cross entropy-genetic algorithm: a case research in Indonesia. Production \& Manufacturing Research, 4(1), 90-113

Utama, D. M., Ardiansyah, L. R., \& Garside, A. K. (2019). Penjadwalan Flow Shop untuk Meminimasi Total Tardiness Menggunakan Algoritma Cross Entropy-Algoritma Genetika. Jurnal Optimasi Sistem Industri, 18(2), 133-141.

Ying, K. C., \& Lin, S. W. (2020). Solving no-wait job-shop scheduling problems using a multi-start simulated annealing with bi-directional shift timetabling algorithm. Computers \& Industrial Engineering, 106615. 